\title{
Vakum Fermantasyon Uygulamasının Glutensiz Ekmeğin Kalite Kriterleri Üzerine Etkisinin İncelenmesi
}

\author{
Sezin TUTA ŞIMȘEK*1(D) \\ ${ }^{1}$ Çankırı Karatekin Üniversitesi, Mühendislik Fakültesi, Gıda Mühendisliği Bölümü, 18100, Çankırı, Türkiye
}

(Alınış / Received: 31.12.2019, Kabul / Accepted: 08.06.2020, Online Yayınlanma / Published Online: 20.08.2020)

\author{
Anahtar Kelimeler \\ Glutensiz ekmek \\ Fermantasyon \\ Vakum
}

\begin{abstract}
Özet: $\mathrm{Bu}$ çalışmada vakum (düşük basınçta) fermantasyonun glutensiz ekmeğin kalite kriterleri üzerine etkisi değerlendirilmiştir. Vakum fermantasyon parametrelerinin (vakum basıncı ve fermantasyon süresi) optimizasyonu için tam faktöriyel deney tasarımı tabanlı istenirlik fonksiyonu yaklaşımı kullanılmıştır. Faktörler üzerine etki eden yanıtlar hamurun reolojik özellikleri (konsistens, sıkılık, viskozite indeksi, kohesiflik) olarak belirlenmiştir. Optimizasyon işlemi ile optimum vakum basıncı ve fermantasyon süresi $30 \mathrm{kPa}$ ve $40 \mathrm{dk}$ olarak belirlenmiștir. Konvansiyonel yöntemle ve düşük basınçta fermante edilen glutensiz ekmek örneklerinin toplam su kaybı, renk ve tekstür özellikleri karşılaştırılmıştır. Her iki yöntemle üretilen glutensiz ekmek örneklerinin kalite özellikleri arasındaki farkın istatistiksel olarak önemli olmadığı (P>0,05) gözlemlenmiştir. Bu çalışma ile glutensiz ekmek üretiminde vakum fermantasyon uygulamasının önemli bir potansiyele sahip olduğu görülmüştür.
\end{abstract}

\section{Investigation of Vacuum Fermentation on Quality Criteria of Gluten-Free Bread}

\section{Keywords}

Gluten-free bread

Fermentation

Vacuum

\begin{abstract}
In this study, effect of vacuum (low-pressure) fermentation on quality attributes of gluten-free bread was evaluated. A full-factorial experimental design based desirability function approach was used in order to determine optimum vacuum fermentation parameters (vacuum pressure and fermentation time). Responses were identified as rheological properties (consistency, firmness, index of viscosity and cohesiveness) of gluten-free dough. As a result of optimization 30 $\mathrm{kPa}$ and $40 \mathrm{~min}$ were determined as optimum vacuum pressure and fermentation time, respectively. Total water loss, color and texture properties of gluten-free bread samples fermented by conventional method and optimum vacuum conditions were compared and statistically insignificant differences $(P>0,05)$ were found between two groups. This study showed that vacuum fermentation has an important potential in gluten-free bread production.
\end{abstract}

\section{Giriş}

Fermantasyon, ekmek üretiminde uygulanan önemli aşamalardan biridir. Karıştırma ve fermantasyon ekmekte hava kabarcıkları içeren yapı ve aroma bileşenlerinin oluşmasını sağlamaktadır. [1]. Ekmek mayası (Saccharomyces cerevisiae) ekmek üretiminde birincil olarak kullanılan kabartma ajanıdır. Maya hücreleri hamurda bulunan fermante olabilen şekerleri kullanarak fermantasyon sırasında karbondioksit ve etanol oluşumuna bu da firınlama esnasında ekmeğin kabarmasına neden olmaktadır. Fermantasyon metabolitlerinin oluşması, hamur bileșenleri (şekerin kullanılabilirliği, tuz, mineral, vitamin, nitrojen kaynağı), hamur fermantasyon koşulları (fermantasyon sicaklığı ve süresi), maya önbüyütme koşulları ve maya türünün genetik yapısı gibi farklı faktörlerden etkilenmektedir [2,3]. Yoğurma ile hava (oksijen ve nitrojen) hamur içerisine hapsolmakta ve böylece hava kabarcıkları oluşmaktadır. Maya aktivitesi yoğurma ile başlar ve fermantasyon sirasinda devam eder. Karbondioksitin yüksek çözünürlükte olması ve gaz kabarcıklarının oluşumunda yetersiz olması ve oksijenin mayalar tarafından kullanılması nedeni ile gaz çekirdeği oluşumunda nitrojen etkilidir [1]. Fermantasyon sertlik, esneklik, hacim ve kohesiflik gibi ekmeğin son kalitesini etkileyen önemli bir ara aşamadır [4]. Ekmek hamuru hacminin üç katına çıkması için bir saatten fazla süre gerekebilmektedir bu nedenle fermantasyon ekmek üretiminde en 
fazla zaman harcanan süreçtir. Ekmek üretiminde kullanılan enerjinin \%10-15'ini fermantasyon kabinlerinde harcanan enerji olușturmaktadır. Bu nedenle fermantasyon süresini kısaltmak ve optimize etmek önem arz etmektedir [1]. Glutensiz ürünlerin gluten içeren ürünlere nazaran daha yüksek fiyatlara satılmaları bu durumu daha önemli hale getirmektedir. Yapılan bir araştırmada glutensiz ürünlerin gluten içerenlere göre \% 22-334 arasında daha yüksek fiyata sahip olduğunu rapor edilmiștir [5]. Literatürde fermantasyon süresini kısaltmak amaciyla ohmik ısıtma [1], ultrases [4], ve mikrodalga [6] gibi alternatif teknolojilerden yararlanıldı̆̆ görülmektedir. $\mathrm{Bu}$ çalışmada fermantasyon işlemi vakumda (düşük basınç ortamında) gerçekleştirilmiştir. Gıda alanında vakum uygulamaları kızartma [7, 8], soğutma [9, 10], pişirme [11], firınlama [12-14] ve kurutma [15] proseslerinde kullanılmaktadır. $\mathrm{Bu}$ işlemlerde ortam basıncının düşüşü suyun kaynama noktasında düşüşe neden olmaktadır bu da proseslerde avantaj sağlamaktadır. Ekmek üretiminin karıștırma aşamasında vakum uygulanarak ekmek hacmine ve gözenek yapısına etkisi ile ilgili çalışmalar literatürde mevcuttur [16]. Ancak vakum uygulamasının fermantasyon aşamasında kullanılması ile ilgili çalışmaya literatürde rastlanmamaktadır. Bu bilgiler ışığında bu çalışmada,

- Glutensiz ekmek üretiminde vakum fermantasyonun uygulanabilirliği araştırılmış ve bu amaçla çok yanıtlı optimizasyon çalışması gerçekleştirilmiş,

- Optimum vakum basıncı ve sürede fermante edilen glutensiz ekmek hamuru ile elde edilen glutensiz ekmek örneklerinin kalite kriterleri (toplam su kaybı, renk, tekstür) incelenmiş ve konvansiyonel yöntemle fermante edilen glutensiz ekmek örnekleriyle karşılaştırılmıştır.

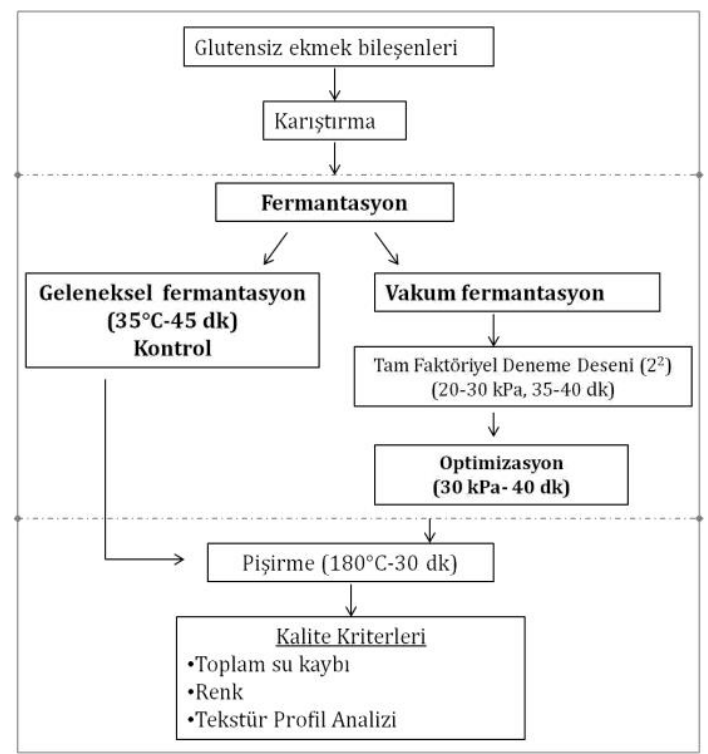

Şekil 1. Deney yapım aşamaları.

\section{Materyal ve Metot}

\subsection{Glutensiz Ekmek Hazırlanması}

Glutensiz ekmek üretimi için Tuta Şimşek (2020) 'de kullanılan formülasyon ve hamur yapım aşamaları uygulanmıștır [12]. Geleneksel fermantasyon işleminde optimum fermantasyon sıcaklığı olan $35^{\circ} \mathrm{C}$ 'dir [1]. Bu nedenle glutensiz ekmek hamurları $35^{\circ} \mathrm{C}$ de $45 \mathrm{dk}$ süreyle fermante edilmiştir (kontrol). Vakum fermantasyonu için uygulanan parametreler için tam faktöriyel tasarım tabanlı deneme deseni uygulanmış ve optimum işletim parametreleri belirlenmiştir. Deney yapım aşamaları Şekil 1'de gösterilmektedir.

\subsection{Vakum Fermantasyon Koşullarının Belirlenmesi}

\subsubsection{Faktörlerin ve Seviyelerinin Belirlenmesi}

Optimum vakum basıncı ve fermantasyon süresinin belirlenmesi için iki faktör ve iki seviyeli $\left(2^{2}\right)$ tam faktöriyel deney tasarımı uygulanmıştır.

Tablo 1. Faktör ve seviyeler

\begin{tabular}{lll}
\hline Faktörler & \multicolumn{2}{c}{ Seviyeler } \\
\hline Vakum basıncı & 20 & 30 \\
Fermantasyon Süresi (dk) & 35 & 40 \\
\hline
\end{tabular}

Vakum fermantasyon için vakum pompası (Model MVP6, Woosun, Kore) ile birlikte vakum firın (Model OV-11,Jeiotech, Güney Kore) kullanılmıştır. Faktör seviyelerinin belirlenmesi amaciyla öncelikle ön denemeler gerçekleştirilmiștir. Fermantasyon sicaklığı kontrolle benzer olarak $35^{\circ} \mathrm{C}$ 'de gerçekleştirilmiştir. Yapılan ön denemelerde düşük basınçta (20 kPa ve $30 \mathrm{kPa}$ ) kontrolle benzer sürede (45 dk) fermantasyon uygulandiğında hamur yapısının olumsuz etkilendiği; fermantasyon $30 \mathrm{dk}$ uygulandığında ise fermantasyonun neredeyse gerçekleşmediği gözlemlenmiştir. $\mathrm{Bu}$ nedenle fermantasyon süresi 35 ve $40 \mathrm{dk}$ olarak belirlenmiștir. Ortam basıncı ile gazların hacmi ters orantılıdır bu nedenle fermantasyon sirasinda hamurda oluşan gaz kabarcıklarının patlamasını engellemek için vakum basıncı $20 \mathrm{kPa}$ ve $30 \mathrm{kPa}$ (mutlak basınç değerleri sırasıyla $81,3 \mathrm{kPa}$ ve 71,3 $\mathrm{kPa}$ ) olarak seçilmiștir. $\mathrm{Bu}$ parametreler göze alınarak belirlenen faktör ve seviyeleri Tablo 1'de gösterilmiştir. $\mathrm{Bu}$ faktörlerin hamurun reolojik özellikleri (yanıtlar) üzerine etkisi değerlendirilerek optimum faktör seviyeleri belirlenmiștir.

\subsubsection{Hamurun Reolojik Özelliklerinin Belirlenmesi}

Glutensiz ekmek hamurunun reolojik özelliklerinin belirlenmesi amacıyla Back Extrusion Rig ile birlikte tekstür analiz cihazı (Model TA-XT2i, Stable Micro Systems Ltd., Surrey, UK, 30 N load cell) kullanılmıştır. Fermantasyon sonrasında ekmek 
Tablo 2. Deney tasarımı ve glutensiz ekmek hamurunun reolojik özellikleri

\begin{tabular}{ccllll}
\hline $\begin{array}{c}\text { Vakum } \\
\text { basıncı }(\mathrm{kPa})\end{array}$ & $\begin{array}{c}\text { Fermantasyon } \\
\text { süresi }(\mathrm{dk})\end{array}$ & $\begin{array}{l}\text { Sikllı } \\
(\mathrm{g})\end{array}$ & $\begin{array}{l}\text { Konsistens } \\
\text { (g.sec) }\end{array}$ & $\begin{array}{l}\text { Kohesiflik } \\
(\mathrm{g})\end{array}$ & $\begin{array}{l}\text { Viskozite indeksi } \\
\text { (g.sec) }\end{array}$ \\
\hline 20 & 35 & $104,1 \pm 15,2$ & $2187,3 \pm 352,5$ & $-148,2 \pm 12,3$ & $-346,5 \pm 46,7$ \\
30 & 35 & $93,7 \pm 7,6$ & $1717,4 \pm 111,8$ & $-135,1 \pm 9,0$ & $-293,2 \pm 17,2$ \\
20 & 40 & $93,2 \pm 3,9$ & $1865,3 \pm 148,3$ & $-138,4 \pm 7,5$ & $-298,3 \pm 13,1$ \\
30 & 40 & $108,1 \pm 10,5$ & $2125,6 \pm 279,2$ & $-152,2 \pm 4,4$ & $-341,7 \pm 39,2$ \\
\hline
\end{tabular}

Tablo 3. Kontrol ve optimum koșullarda fermente edilen hamurların reolojik özellikleri

\begin{tabular}{ccccccc}
\hline & $\begin{array}{c}\text { Vakum } \\
\text { basincl }(\mathrm{kPa})\end{array}$ & $\begin{array}{c}\text { Fermantasyon } \\
\text { süresi }(\mathrm{dk})\end{array}$ & Sıkılık (g) & $\begin{array}{c}\text { Konsistens } \\
\text { (g.sec) }\end{array}$ & Kohesiflik (g) & $\begin{array}{c}\text { Viskozite indeksi } \\
\text { (g.sec) }\end{array}$ \\
\hline Kontrol & 0 & 45 & $112,0 \pm 7,4$ & $2245,3 \pm 74,5$ & $-156,0 \pm 1,2$ & $-350,2 \pm 15,4$ \\
Opt-VF & 30 & 40 & $108,1 \pm 10,5$ & $2125,6 \pm 279,2$ & $-152,2 \pm 4,4$ & $-341,7 \pm 39,2$ \\
\hline & & $\boldsymbol{P}(\boldsymbol{P = 0 , 9 5 )}$ & $\mathbf{0 , 7 2 9}$ & $\mathbf{0 , 6 1 7}$ & $\mathbf{0 , 2 9 1}$ & $\mathbf{0 , 8 0 5}$ \\
\hline
\end{tabular}

hamurları $50 \mathrm{~mm}$ çaplı örnek kabına aktarılmış, disk (35 mm çaplı ve $1 \mathrm{~mm} / \mathrm{s}$ hızda ) ile hamurun \% 30 derinliğine nüfuz edecek şekilde sıkıştırma gerçekleştirilmiştir [17]. Analizler 3 tekrar gerçekleştirilmiştir. Analiz sonucunda elde edilen kuvvet-zaman grafiğinden yararlanılarak hamurun sıkılık, konsistens, kohesiflik ve viskozite indeksi değerleribelirlenmiştir. Sıkılık, hamurun ekstrüzyonu sırasında kuvvet-zaman eğrisinde görülen en yüksek kuvvet değeri; konsistens, ekstrüzyon sırasında elde edilen eğrinin altında kalan alan; kohesiflik, probun geri çekilmesi sırasında negatif bölgede elde edilen en yüksek kuvvet değeri ve viskozite indeksi negatif bölgede elde edilen eğrinin altında kalan alan olarak tanımlanmıştır [18].

\subsection{3. İstenirlik Fonksiyonu Yaklaşımı ile Çok Yanitlı Optimizasyon}

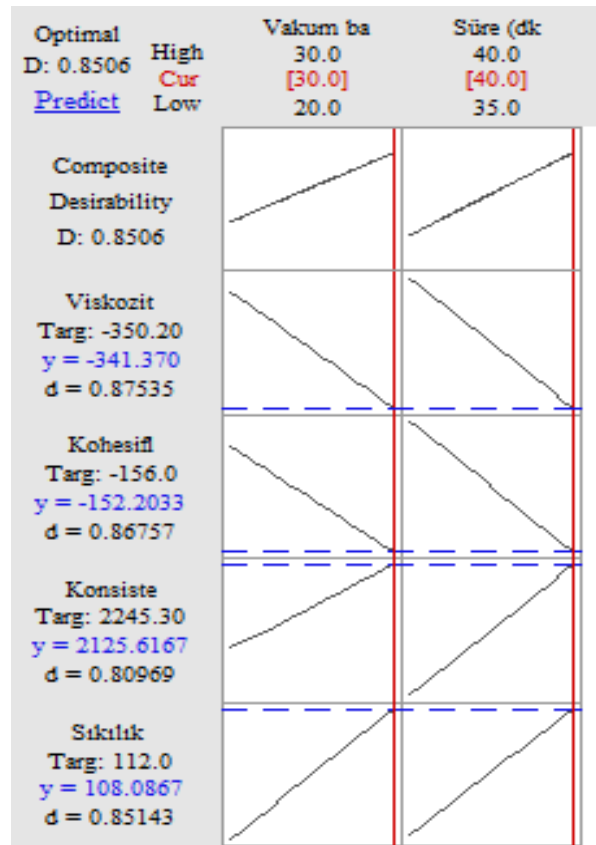

Şekil 2. İstenirlik fonksiyonu yaklaşımı ile çok yanıtlı optimizasyon.

Optimizasyon işlemi için tam faktöriyel deney tasarımı tabanlı istenirlik fonksiyonu yaklaşımı uygulanmış bu amaçla MINITAB $^{\circledR}$ programı kullanılmıştır. Buna göre düşük basınçta fermantasyon prosesi için $2^{2}$ tam faktöriyel deney tasarımı ve bu koşullarda fermante edilen hamurun reolojik özellikleri (konsistens, sıkılık, kohesiflik, viskozite indeksi) Tablo 2'de gösterilmektedir. Vakum fermantasyon koşullarının optimizasyonu için hedef uygulanan vakum basincl ve fermantasyon süresinde kontrolle benzer hamur özelliklerinin elde edilmesidir. Buna göre optimizasyon işleminde hamur reolojik özelliklerinin kontrolle benzer olduğu $30 \mathrm{kPa}$ vakum basıncl ve $40 \mathrm{dk}$ fermantasyon süresi optimum vakum fermantasyon koşulları olarak belirlenmiștir (Şekil 2). Kontrol ve optimal seviyelerde fermante edilen hamur örneklerinin reolojik özellikleri arasındaki fark eşleşmiş t-testi $(\mathrm{P}=0,95$, Microsoft Excel 2010) ile belirlenmiştir. Optimal seviyede vakumda fermante edilen ve kontrol hamur örneklerinin reolojik özellikleri arasındaki farkın istatistiksel olarak önemli olmadığı $(P>0,05)$ gözlemlenmiştir (Tablo 3$)$.

\subsection{Glutensiz Ekmek Kalite Kriterlerinin Belirlenmesi}

Optimal vakum basınç-süre kombinasyonunda ve tamamen atmosferik basınçta fermante edilen hamurların pişirilmesi ile elde edilen glutensiz ekmek örneklerinin kalite özellikleri karşılaştırılmıştır. Kontrol ve optimal vakum fermantasyon koşullarında fermante edilen glutensiz ekmek hamurları $180^{\circ} \mathrm{C}$ 'de $30 \mathrm{dk}$ süreyle pişirilmiştir. Bu amaçla fanlı etüv (Model MST 55, Teklab, Türkiye) kullanılmıştır. Pişirme sonlandıktan bir saat sonra tekstür profil analizi (sertlik, çiğnenebilirlik, esneklik, kohesiflik, yapışkanlık, resilience) renk, ağırlık kaybı analizleri gerçekleştirilmiştir. Bu amaçla Tuta Şimşek (2020)'de kullanılan yöntemler uygulanmıştır [12]. Analizler iki tekrar iki paralel gerçekleştirilmiştir.

\section{4. İstatistiksel Analiz}

Konvansiyonel ve optimal vakum fermantasyon koşullarında fermente edilen hamurlardan elde edilen glutensiz ekmek örneklerinin kalite özellikleri arasındaki farkın istatistiksel analizi için eşlenmiş t-testi $(\mathrm{P}=0,95)$ uygulanmıştır. Bu amaçla Microsoft Excel 2010 programı kullanılmıștır. 


\section{Bulgular}

\subsection{Vakum Fermantasyonda Faktörlerin Yanıtlar Üzerine Etkisi}

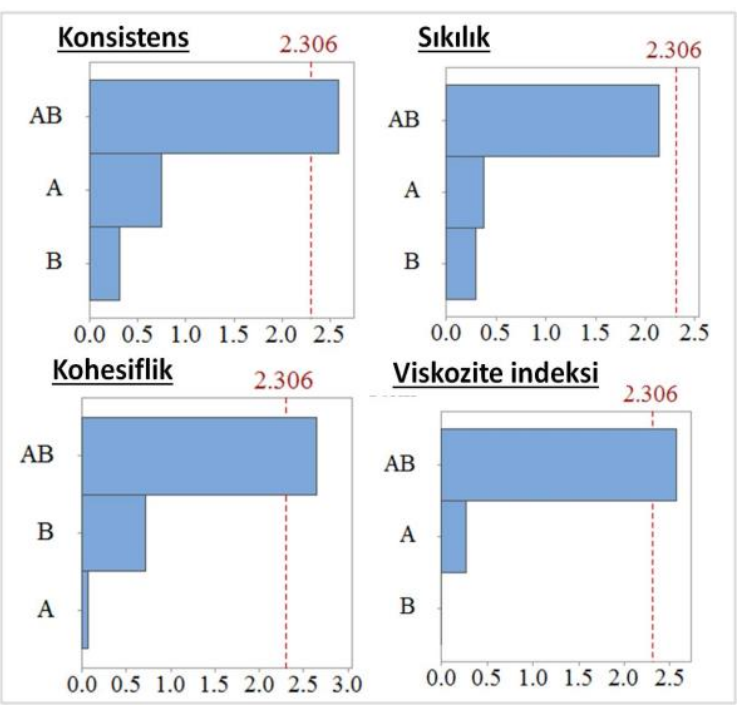

Şekil 3. Pareto etki grafikleri (A: vakum basıncl, B: fermantasyon süresi).

Vakum fermantasyon parametrelerinin (vakum basıncı (A) ve fermantasyon süresi (B)) hamurun konsistens, sıkılık, kohesiflik ve viskozite indeksi değerleri üzerine etkisi pareto etki grafikleri ile değerlendirilmiștir (Şekil 3). Hamurun reolojik özelliklerini vakum basıncı ve fermantasyon süresinin ayrı ayrı etkilemediği gözlemlenmiștir. Ancak vakum basıncl ve fermantasyon süresinin birlikte etkisinin (AB) konsistens, kohesiflik ve viskozite indeksi üzerine etkisinin istatistiksel olarak önemli olduğu, sıkılık değeri üzerine etkisinin istatistiksel olarak önemli olmadığı görülmüştür.

Vakum basıncı ve fermantasyon süresinin hamur reolojik özellikleri üzerine etkisi Şekil 4'te gösterilmektedir. Vakum basıncı ve fermantasyon süresindeki artış daha yüksek konsistens, sıkılık, viskozite indeksi ve kohesiflik değerlerine sahip hamur yapısı elde edilmesine neden olmaktadır.

\subsection{Glutensiz Ekmek Kalite Kriterlerinin Değerlendirilmesi}

Konvansiyonel yöntemle ve düşük basınçta fermante edilen glutensiz ekmek hamurlarının pişirilmesi ile elde edilen ekmek örneklerinin kalite özellikleri Tablo 4'te gösterilmektedir. Ağırlık kaybı, tekstür profil analizi ve renk değerlerindeki değișimin istatistiksel olarak önemli olmadığ görülmüștür $(P>0,05)$.
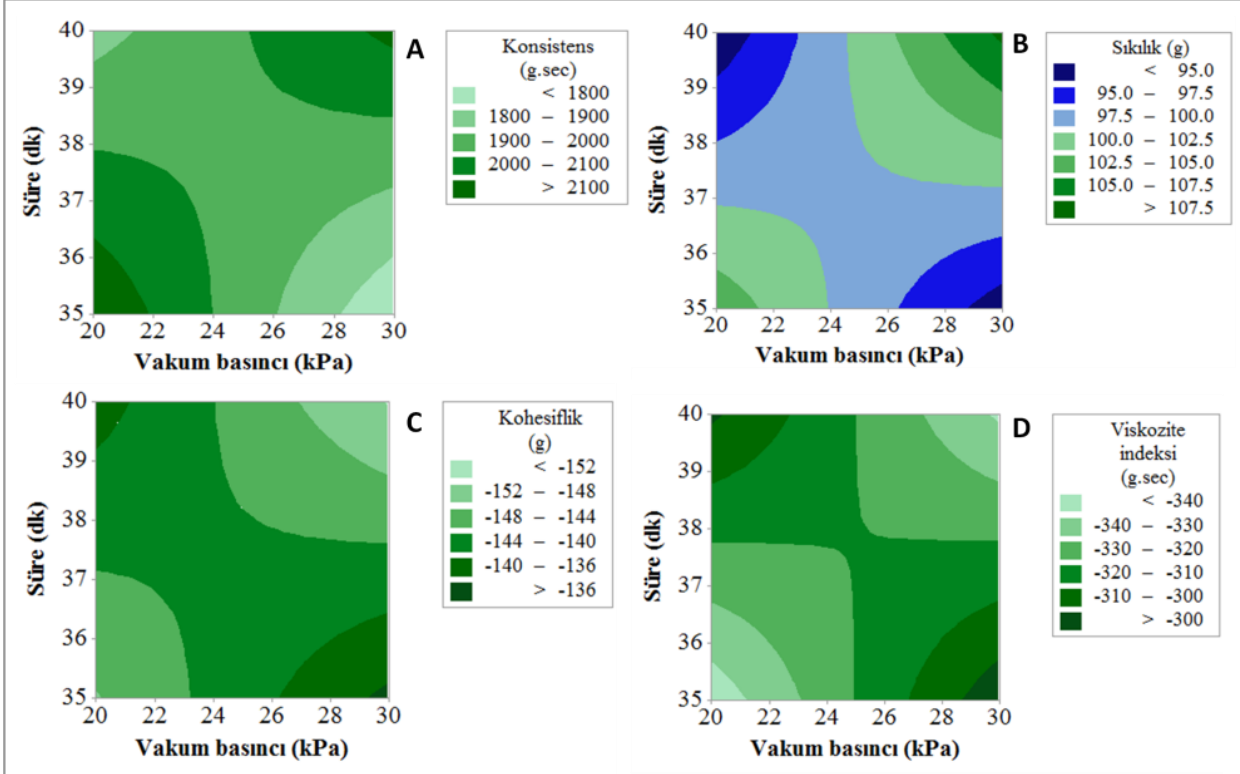

Şekil 4. Faktörlerin yanıtlar üzerine etkileri (A: konsistens, B:sıkılık, C: kohesiflik, D:viskozite indeksi).

Tablo 4. Kontrol ve vakum fermantasyon ile üretilen glutensiz ekmeklerin kalite kriterleri

\begin{tabular}{llllc}
\hline Parametreler & & Kontrol & OPT-VF & P (P=0,95) \\
\hline Toplam su kaybı & & $17,97 \pm 0,81$ & $18,18 \pm 0,56$ & $\mathbf{0 , 7 7 2}$ \\
\hline \multirow{4}{*}{ Tekstür Profil Analizi } & Sertlik (g) & $3710,66 \pm 321,94$ & $3546,00 \pm 793,99$ & $\mathbf{0 , 6 1 7}$ \\
& Çiğnenebilirlik & $1159,20 \pm 120,28$ & $947,55 \pm 177,41$ & $\mathbf{0 , 9 2 8}$ \\
& Esneklik & $0,62 \pm 0,02$ & $0,58 \pm 0,03$ & $\mathbf{0 , 0 6 7}$ \\
& Kohesiflik & $0,50 \pm 0,03$ & $0,46 \pm 0,02$ & $\mathbf{0 , 0 7 0}$ \\
& Yapişkanlık (g.sec) & $-5,82 \pm 2,67$ & $-10,05 \pm 5,74$ & $\mathbf{0 , 3 4 6}$ \\
\cline { 2 - 4 } Renk & Resilience & $0,22 \pm 0,02$ & $0,20 \pm 0,01$ & $\mathbf{0 , 1 2 9}$ \\
& $L$ & $75,2 \pm 1,86$ & $75,49 \pm 1,20$ & $\mathbf{0 , 8 6 4}$ \\
& $a^{*}$ & $0,92 \pm 1,02$ & $0,38 \pm 0,13$ & $\mathbf{0 , 3 8 0}$ \\
\hline
\end{tabular}




\section{Tartışma ve Sonuç}

\subsection{Vakum Fermantasyonunda Faktörlerin Yanıtlar Üzerine Etkisinin Değerlendirilmesi}

Gazların hacmi basınç ile ters orantılı olarak değișmektedir. Vakum basıncındaki azalma mutlak basincın düşmesine ( $\left.P_{\text {mutlak }}=\mathrm{P}_{\text {atm }}-\mathrm{P}_{\text {vakum }}\right)$ ve buna bağlı olarak ekmek hamuru içerisinde oluşan gaz kabarcıklarının hacminin artmasına neden olmaktadır [14]. Vakum basıncının artışı ile mutlak basıncın düşmesi ve fermantasyon süresinin artıșı daha fazla sayıda daha yüksek hacimli hava kabarcıklarının oluşmasına neden olmuş olabilir. Böylece daha fazla sayıda ve daha hacimli hava kabarcıkları hamur içerisine hapsolmuștur. Bu nedenle vakum basıncı ve fermantasyon süresi birlikte hamurun reolojik özelliklerini etkilemektedir. Pareto etki grafiklerinde görüldügü gibi bu ikili etki (AB) hamurun konsistens, kohesiflik, viskozite indeksi değerlerini istatistiksel olarak önemli derecede etkilemektedir (Șekil 2). Gao vd. (2017), ekmek hamur bileșenlerinin vakumda karıștırılması ile daha kıvamlı hamur elde edildiğini rapor etmişlerdir ve bunun nedeni büyük gaz kabarcıklarının dağılması ile küçük gaz kabarcıklarının oluşması daha yoğun (konsistensi yüksek) hamur oluşması olarak belirtmişlerdir [16].

Hamurun kıvamı konsistens, akmaya karşı gösterdiği direncin bir ölçüsü viskozite indeksi ve kohesiflik ise hamurdaki iç bağların gücü ile ilgili bilgi vermektedir [18]. Vakum basincı ve fermantasyon süresindeki artış bu değerleri artırıcı etkiye sahiptir (Şekil 4). Bu değerler içerisinden kohesiflik değeri ekmek kalitesi ile ilgili bilgi veren iyi bir indikatördür. Yapıda gluten olmaması nedeniyle glutensiz hamurların kohesifliği düşük olmakta bu nedenle kohesifliği artırmak önem kazanmaktadır. Yüksek kohesifliğe sahip hamur ile daha yüksek özgül hacme sahip ve daha yumuşak ekmek elde edilebilmektedir [19]. Kontrolle benzer özelliklerde hamur elde etmek için yapılan optimizasyon işleminde optimum ișlem parametrelerinin (OPT-VF) (Tablo 3) sıkılık, konsistens, kohesiflik ve viskozite indeksi değerlerinin Tablo 2'de görülen en yüksek değerler olduğu gözlemlenmektedir. Bu son üründe ekmek özelliklerinin kontrolle benzer olması açısından önemlidir.

\subsection{Glutensiz Ekmek Kalite Kriterlerinin Değerlendirilmesi}

Fırınlama aşamasında fermante hamur ısı ve kütle transferinin etkisiyle yapısal değişikliğe uğramaktadır. İlk aşamada ısı transferinin etkisiyle mayanın $\mathrm{CO}_{2}$ üretimi artar $\left(50-60^{\circ} \mathrm{C}\right.$ 'de maya inaktive olana kadar), gaz genleşir, $\mathrm{CO}_{2}$ buharlaşır, etanol çözünebilir hale geçer ve su buharlaşır. Hamur yeterli sıcaklığı ulaştıktan sonra nişasta jelatinizasyonu ve protein denaturasyonu ile ekmek yapısı oluşur [3]. Toplam su kaybı, tekstür ve renk ekmek ürünlerinin bașlıca kalite özelliklerindendir. Glutensiz ekmeğin kalite özelliklerini fermante hamurun reolojik özellikleri etkilemektedir [20].

Kontrol ve vakum fermantasyon ile üretilen glutensiz ekmeklerin kalite kriterleri Tablo 4'de gösterilmektedir. İstenirlik fonksiyonu yaklaşımı ile yapılan çok yanıtlı optimizasyon işlemi ile amaç konvansiyonel ve vakumda fermante edilen hamur özelliklerinin birbirine benzer olmasıdır. $\mathrm{Bu}$ nedenle beklenildiği gibi son üründe belirlenen kalite özellikleri birbiri ile benzerdir. Kontrol ve vakum fermantasyon ile üretilen glutensiz ekmek örneklerinin toplam su kaybı, tekstür profil analizi, renk parametreleri arasındaki farklılık istatistiksel olarak önemli değildir $(P>0,05)$.

Vakum fermantasyonla üretilen ekmeklerin kontrole göre daha yapıșkan, daha yumuşak, daha az çiğnenebilir, esnek ve kohesif olduğu görülmüştür (Tablo 4). En belirgin farklılık vakum fermantasyon ile üretilen ekmeklerin yapışkanlık değerinde gözlemlenmiş, bu örneklerin daha yapışkan olduğu görülmüştür. HPMC, hidrofilik ve hidrofobik özellikleri ile fermantasyon sırasında hamurda ara yüzey aktivitesi ve ısıtma sırasında jel ağ yapı oluşumuna neden olmaktadır [19]. Ortam basıncının düșmesiyle gaz kabarcıklarının hacmi artmış ve bu durumun HPMC ara yüzey özelliklerini zayıflatarak jel ă yapıyı etkileyebileceği düşünülmüştür. Böylece daha yapışkan ekmek içyapısı oluşmuş olabilir ancak bu farklılık istatistiksel olarak önemli değildir $(P>0,05)$. Hamurun reolojik özellikleri ile ilişkilendirildiğinde sıkılık, konsistens, kohesiflik ve viskozite indeksi değeri daha düşük olan vakumda fermante edilen hamur (Tablo 3) ile elde edilen ekmek örneklerinin daha yumuşak ve daha düșük kohesiflik değerine sahip olduğu gözlemlenmiştir. Yüksek konsistense sahip hamurlar, hamur yapisının sert olması nedeniyle gazların genleşememesine ve daha sert ekmek elde edilmesine neden olmaktadır. Düșük konsistensli hamurlarda ise gevșek hamur yapısı gazların yapıda kalmayarak ekmek yapısının daha yumuşak olmasına neden olmaktadır [21]. Renk parametrelerinden $a^{*}$ değeri ekmek kabuğunun esmerleşmesi ve kırmızılık değeri hakkında bilgi vermektedir [22]. İstatistiksel olarak anlaml olmamasına rağmen vakum fermantasyonla üretilen ekmeklerin a* değerinin daha düşük olduğu görülmüştür. Glutensiz ekmek örneklerinin açık renkli olması tüketici beğenisini etkileyen önemli unsurlardandır. $\mathrm{Bu}$ nedenle daha esmer yani kırmızılık değeri daha yüksek kabuk rengi arzu edilmektedir. Vakum fermantasyon ile daha açlk renkli glutensiz ekmek üretilmesi dezavantaj olarak değerlendirilebilir.

Yapılan bu çalışma ile, 
- Ekmek üretiminde fermantasyon işlemi sırasında vakum fermantasyon koşulları istenirlik fonksiyonu yaklaşımı ile çok yanıtlı olarak optimize edilmiștir. Optimum vakum basıncı (30 kPa) ve fermantasyon süresi $(40 \mathrm{dk})$ parametrelerinde fermante edilen hamurun konvansiyonel yöntemle (atmosferik basınçta 45 $\mathrm{dk}$ süreyle gerçekleștirilmiştir) fermante edilmiş hamur ile benzer reolojik özelliklere sahip olduğu görülmüştür $(P>0,05)$.

- Bu yöntemle fermantasyon işlemi daha kısa sürede gerçekleştirilmiştir. Enerji sarfiyatının önemli bir kısmının gerçekleştirildiği fermantasyon aşamasında süre kısaltılması enerji tasarrufu açısından önemli bir avantaj sağlamaktadır. Ancak pompa kullanımının neden olduğu enerji sarfiyatı da dikkate alınarak maliyet analizi yapılmalıdır.

- Konvansiyonel yöntemle karşılaştırıldığında vakum fermantasyonla üretilen ekmek örneklerinin benzer kalite özelliklerine sahip olduğu gözlemlenmiştir. Bu çalışma, glutensiz ekmek üretiminde vakum fermantasyonun uygulanabilirliğinin önemli bir potansiyele sahip olduğunu göstermiștir.

\section{Kaynakça}

[1] Gally, T., Rouaud, O., Jury, V., Havet, M., Ogé, A., Le-Bail, A. 2017. Proofing of bread dough assisted by ohmic heating. Innovative Food Science \& Emerging Technologies, 39, 55-62.

[2] Struyf, N., Van der Maelen, E., Hemdane, S., Verspreet, J., Verstrepen, K. J., Courtin, C. M. 2017. Bread dough and baker's yeast: An uplifting synergy. Comprehensive Reviews in Food Science and Food Safety, 16(5), 850-867.

[3] Martínez, M. M., Gómez, M. 2017. Rheological and microstructural evolution of the most common gluten-free flours and starches during bread fermentation and baking. Journal of Food Engineering, 197, 78-86.

[4] Luo, D., Wu, R., Zhang, J., Zhang, K., Xu, B., Li, P.,Li, X. 2018. Effects of ultrasound assisted dough fermentation on the quality of steamed bread. Journal of Cereal Science, 83, 147-152.

[5] Panagiotou, S., Kontogianni, M. D. 2017. The economic burden of gluten-free products and gluten-free diet: a cost estimation analysis in Greece. Journal of Human Nutrition And Dietetics, 30(6), 746-752.

[6] Ozmutlu, O., Sumnu, G., Sahin, S. 2001. Assessment of proofing of bread dough in the microwave oven. European Food Research and Technology, 212(4), 487-490.

[7] Mariscal, M., Bouchon, P. 2008. Comparison between atmospheric and vacuum frying of apple slices. Food Chemistry, 107(4), 15611569.

[8] Belkova, B., Hradecky, J., Hurkova, K., Forstova, V., Vaclavik, L., Hajslova, J. 2018. Impact of vacuum frying on quality of potato crisps and frying oil. Food Chemistry, 241, 51-59.

[9] Novotni, D., Špoljarić, I. V., Drakula, S., Čukelj, N., Voučko, B., Ščetar, M., Ćurić, D. 2017. Influence of barley sourdough and vacuum cooling on shelf life quality of partially baked bread. Food Technology and Biotechnology, 55(4), 464.

[10] Ozturk, H. M., Ozturk, H. K., Koçar, G. 2017. Microbial analysis of meatballs cooled with vacuum and conventional cooling. Journal of Food Science and Technology, 54(9), 28252832.

[11] da Silva, F. L., de Lima, J. P., Melo, L. S., da Silva, Y. S., Gouveia, S. T., Lopes, G. S., Matos, W. O. 2017. Comparison between boiling and vacuum cooking (sous-vide) in the bioaccessibility of minerals in bovine liver samples. Food Research International, 100, 566-571.

[12] Tuta Şimşek, S. 2020. Evaluation of PartialVacuum Baking for Gluten-Free Bread: Effects on Quality Attributes and Storage Properties. Journal of Cereal Science, 91, 1-7.

[13] Palazoğlu, T. K., Coşkun, Y., Tuta, S., Mogol, B. A., Gökmen, V. 2015. Effect of vacuumcombined baking of cookies on acrylamide content, texture and color. European Food Research and Technology, 240(1), 243-249.

[14] Şimşek, S. T. 2019. Vacuum-combined baking to enhance quality properties of gluten-free cake: Multi-response optimization study. LWT, 116, 1-7.

[15] Wang, J., Law, C. L., Nema, P. K., Zhao, J. H., Liu, Z. L., Deng, L. Z., Xiao, H. W. 2018. Pulsed vacuum drying enhances drying kinetics and quality of lemon slices. Journal of Food Engineering, 224, 129-138.

[16] Gao, J., Tay, S. L., Koh, A. H. S., Zhou, W. 2017. Dough and bread made from high-and lowprotein flours by vacuum mixing: Part 2. Yeast activity, dough proofing and bread quality. Journal of Cereal Science, 77, 275-283.

[17] Korus, J., Witczak, M., Ziobro, R., Juszczak, L. 2009. The impact of resistant starch on characteristics of gluten-free dough and bread. Food Hydrocolloids, 23(3), 988-995.

[18] Ronda, F., Pérez-Quirce, S.,Villanueva, M. 2017. Rheological properties of gluten-free bread doughs: relationship with bread quality. ss 297-334 Ahmed, J. ed. 2016. In Advances in 
food rheology and its applications, Woodhead Publishing, United Kingdom, 528s.

[19] Lazaridou, A., Biliaderis, C. G. Gluten-Free Doughs:Rheological Properties, Testing :Procedures, Methods and Potential Problem. ss 71 Gallagher, E. Ed. 2009. Gluten-free food science and technology. John Wiley \& Sons, United Kingdom, s. 246.

[20] Jha, P. K., Chevallier, S., Cheio, J., Rawson, A., LeBail, A. 2017. Impact of resting time between mixing and shaping on the dough porosity and final cell distribution in sandwich bread. Journal of Food Engineering, 194, 15-23.

[21] Martínez, M. M., Díaz, Á., Gómez, M. 2014. Effect of different microstructural features of soluble and insoluble fibres on gluten-free dough rheology and bread-making. Journal of Food Engineering, 142, 49-56.

[22] Vouris, D. G., Lazaridou, A., Mandala, I. G., Biliaderis, C. G. 2018. Wheat bread quality attributes using jet milling flour fractions. $L W T$, $92,540-547$. 